\title{
Education as Controlling Factor of Invasive Species (Achatina fulica) in an Amazonian City, Brazil
}

\author{
Júlio César Sá-Oliveira ${ }^{1 *}$, Fabrícia Lazamé Araújo², Raimundo Gonçalves Teixeira Filho², \\ Weliton Santos dos Santos ${ }^{2}$, Stephen F. Ferrari ${ }^{3}$ \\ ${ }^{1}$ Ichthyology and Limnology Laboratory, Universidade Federal do Amapá (UNIFAP), Macapá, Brazil \\ ${ }^{2}$ Curso de Licenciatura em Educação do Campo, Universidade Federal do Amapá, Campus Mazagão, Mazagão, \\ Brazil \\ ${ }^{3}$ Department of Ecology, Universidade Federal de Sergipe (UFS), Aracajú, Brazil \\ Email: "juliosa@unifap.br, fabricia.lazame@hotmail.com,raimundo.educ@hotmail.com, \\ weliton.ap2013@gmail.com,ferraricesad@gmail.com
}

Received 13 December 2015; accepted 26 January 2016; published 29 January 2016

Copyright (C) 2016 by authors and Scientific Research Publishing Inc.

This work is licensed under the Creative Commons Attribution International License (CC BY).

http://creativecommons.org/licenses/by/4.0/

(c) (i) Open Access

\section{Abstract}

This study deals with the influence of education on population dynamics of African snail, Achatina fulica, in Santana, Amapá, Brazil. Mollusc samples were taken with the installation of two quadrants of $2.00 \times 2.00$ meters, where there was the presence of animals in five installments (urban land) in each neighborhood. Individuals were collected by manual capture with an effort of 2 hours per plot/sampler and then weighed and measured. Questionnaires were administered to residents of each neighborhood order to know their perception towards the African snail. The results indicated a significant population growth, with 419 molluscs identified as $A$. fulica in the three neighborhoods of the city of Santana. Growth was higher in the center and Paradise neighborhoods, being observed in these two districts the care of cleaning the property was poor, enabling the installation of molluscs. The information reported by residents interviewed indicated that the level of education of the same, as well as its hygienic practices was related to the occurrence and abundance of the species under study. In the Amazon Village neighborhood, the abundance and occurrence were smaller and not different in past study. It became apparent that residents with higher education levels were those which kept hygienic with their property, which directly influenced the non-installation of alien species, contributing indirectly with the environment.

${ }^{*}$ Corresponding author.

How to cite this paper: Sá-Oliveira, J. C., Araújo, F. L., Filho, R. G. T., dos Santos, W. S., \& Ferrari, S. F. (2016). Education as Controlling Factor of Invasive Species (Achatina fulica) in an Amazonian City, Brazil. Creative Education, 7, $159-170$. 


\section{Keywords}

\section{Education, African Snail, Gastropod, Santana-Amapá}

\section{Introduction}

In any society, differences between individuals are consistently observed both in relation to the place they occupy in the social hierarchy as to their individual against the collective behavior (Tedesco, 2012). It is recognized that such differences are associated mainly to educational opportunities, the occupational trajectories, social prestige, access to goods and services and the political and social behavior (Alves \& Soares, 2009). These possibilities undoubtedly the most democratic and accessible is education, because it allows an individual, socio-hierarchically lower, can ascend socio-financially, regardless of their preterit conditions, whether financial, ethnic, religious or political, and makes potentially able to improve their quality of life (Freire, 2002).

Education is one of the key factors in the quest for greater equity and justice in society, however sometimes the expectations surrounding it do not correspond to the real possibilities of generating desired changes (Tedesco, 2012). Education, as a mediator and transformative activity, is one of the actuation means by which individuals realize how society beings, by providing sensitive perception of experiences and be aware of the material conditions of existence; while exercising their capabilities to jointly define the best ways to sustaining life; and by allowing for generation of new knowledge to critically reflect on your daily tasks, transferring them to others, and thus setting up the educational process (Saviani, 1985; Layrargues, 2000; Duarte, 2002).

In modern society, daily activities have been used increasingly specific educational processes, independent of area end of the activity, such as in environmental, health, industrial, primary production, among others, to make them more efficient, effective and efficient (Tamoio, 2000). In the specific case of the questions on the environment, environmental education has become a major tool for mitigating environmental problems, is in understanding the perceptions of individuals about environmental issues, either in practical actions minimizing environmental degradation, or even in the production of relevant knowledge and forwarding suggestions for public policy and legislation for the relevant sectors (Sato, 2002; Abramovay, 2012).

Until the first decade of the $21^{\text {st }}$ century, the theme of exotic and invasive species was rarely worked in Brazilian education. Even in the environmental education literature, little is produced in terms of themes, the most common being those dealing with issues related to waste, deforestation and pollution (Brazil, 1997). Nevertheless, research groups have called attention to the situation of the increasing introduction of invasive alien species, thus promoting discussion of the problem and monitoring and control actions by the government, through its competent bodies (Pimentel et al., 2001).

One of the most aggressive exotic species, in terms of invasion, is the Achatina fulica, regarded as one of the 100 worst invasive alien species (IUCN, 2000), both represent a worldwide environmental problem as to affect human health and the economy (Teles \& Fontes, 2002; Graeff-Teixeira, 2007; Nascimento et al., 2003). This species, once established in the new region, its population can reach very high numbers (Civeyrel \& Simberloff 1996), disturbing the natural and anthropogenic dynamics. In Brazil, A. fulica was introduced in 1980 and was present in most of federative units in the country (Teles et al., 1997; Vasconcellos \& Pile, 2001; Teles \& Fontes, 2002).

It should be noted that invasive species are the second cause of loss of biodiversity in many ecosystems, may cause also change in its structure and function and increased homogenization of a single regional biota (UCS, 2001). Environmental problems can arise because there are no predators to A. fulica in non-native areas of the species, which can pose a threat to the native snails (Angra, 2002; Fisher \& Colley, 2005)

In the state of Amapá-Brazil no precise data on the introduction of A. fulica, however, two studies (Sá-Oliveira et al., 2012; Sá-Oliveira et al., 2013) report the occurrence of this species in two cities in the state (Macapa and Santana), both are located on the banks of the Amazon River in northern Brazil. In both studies it was found young populations of the species, without, however, conclude whether the people were actually in the process of decline or expanding, because the classification used does not allow peremptory conclusions.

The observed in the two previously mentioned studies was that most of molluscs found were related to disturbed areas, with clear problem of waste concentration and lack of hygienic care by residents of the assessed 
real estate. Studies have not made a socioeconomic approach of residents to assess possible relationships of the presence of molluscs in their homes with their educational, financial and political aspects (Sá-Oliveira et al., 2012; Sá-Oliveira et al., 2013).

Given these considerations, the purpose of this study was to conduct a monitoring of the population of $A$. fulica in the same area where was held the past study in the city of Santana and evaluate the socioeconomic conditions of the residents of the properties monitored by analyzing the concepts and perceptions thereof, relating the presence of molluscs their socioeconomic factors, the ability to answer what or what are the main factors contributing to the establishment of invasive species in the investigated areas.

\section{Methodology}

\subsection{Study Area}

The study was conducted in three districts of Santana: Paradise $\left(00^{\circ} 01^{\prime} 41.30^{\prime \prime} \mathrm{S} / 51^{\circ} 10^{\prime} 37.96^{\prime \prime} \mathrm{W}\right)$, Central $\left(00^{\circ} 02^{\prime} 32.05 " \mathrm{~S} / 51^{\circ} 10^{\prime} 21.52^{\prime \prime} \mathrm{W}\right)$ and Amazon village $\left(00^{\circ} 03^{\prime} 05.93^{\prime \prime} \mathrm{S} / 51^{\circ} 09^{\prime} 22.85^{\prime \prime} \mathrm{W}\right)$, which are located in northern, central and southern part of the city, respectively. The city of Santana is located in Amapá state Southeast region between the geographical coordinates $00^{\circ} 02^{\prime} 06^{\prime \prime} \mathrm{S} / 51^{\circ} 10^{\prime} 30^{\prime \prime} \mathrm{O}$, at a distance to the capital 30 $\mathrm{km}$. The estimated population in 2014 by the Brazilian Institute of Geography and Statistics (IBGE, 2010) was 110,565 inhabitants and the area is $1,577,517 \mathrm{~km}^{2}$, resulting in a population density of $69.03 / \mathrm{km}^{2}$ (Figure 1 ). In the city there are five predominant vegetation: thick, dense tropical forest, wetland, lowland forest and ecological tension. The climate is hot and humid rainy tropical and its average temperature is $28^{\circ} \mathrm{C}$.

Paradise neighborhood is located in central city of Santana, is located on land sites and flooded with problems of poor sanitation, public sanitation, poor paving. The Centre district is a commercial area of central Santana. This neighborhood is located on dry, flat land area, with a few properties in flooded area, has better urban structure that Paradise neighborhood, but with clear sanitation problems. The Amazon Village neighborhood is located in east-southern area of Santana, is the one with better urban structure, when compared to other neighborhoods, due to have been designed and built by a mining company Manganese, to live their employees higher level, such as engineers, managers, doctors, etc.

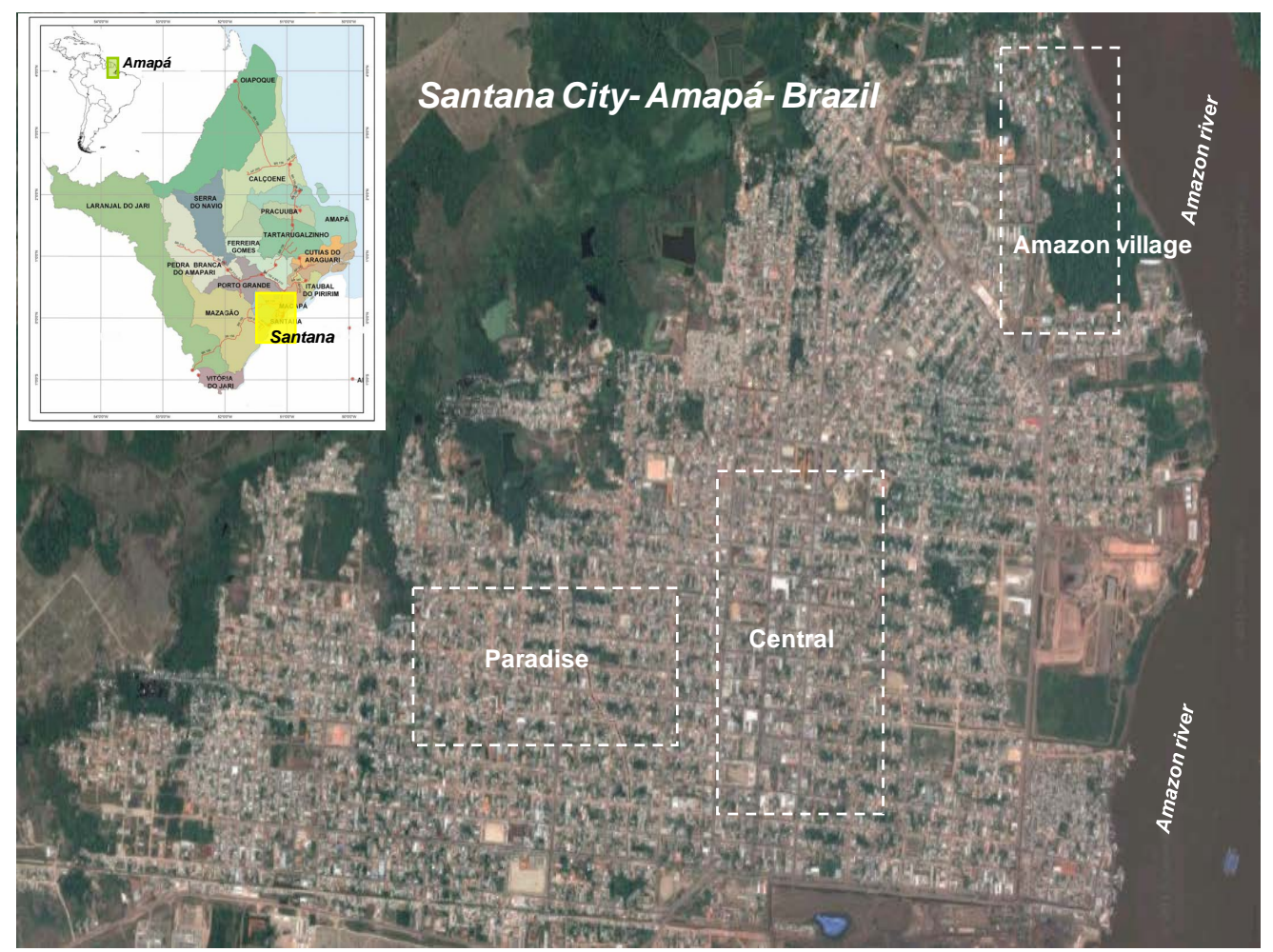

Figure 1. Santana city: Paradise, Central and Amazon village neighborhoods. Source: Google Earth. 


\subsection{Sampling Design, Measurement Procedures and Data Analysis}

\subsubsection{Sampling}

The study was conducted in 2014 and samples were taken with the installation of two quadrants of $2.00 \times 2.00$ meters, where there is the presence of molluscs in five installments (urban lots) of $10.00 \times 25.00$ meters in each district, with a total area of $3750 \mathrm{~m}^{2}$. Individuals were collected by manual capture with an effort of 2 hours per plot. The substrate and vegetation where the molluscs were caught in addition to the environmental variables were photographed parcels and identified as water conditions (flooded and dry), food (fresh and processed) and Property cleaning aspect (appropriate and inappropriate).

\subsubsection{Mensuration}

The individuals collected were fixed in $70 \%$ alcohol and taken to the laboratory of Ichthyology and Limnology-UNIFAP to identification and measurement. For morphometric analysis we used a Vernier caliper with a precision of $0.05 \mathrm{~mm}$, considering the greater length of the shell (the apex to the edge) and weighing $0.01 \mathrm{~g}$ precision scales were used.

\subsubsection{Data Analysis}

Histogram size classes were built $(15 \mathrm{~mm})$ for individuals collected in each neighborhood. Through the size of classes individuals were classified in their stages of life according to the classification proposed by Tomiyama (2002) considers that juvenile snails with 10 - $40 \mathrm{~mm}$ shells; young individuals with shells from 40 to $90 \mathrm{~mm}$ and those with adults over $90 \mathrm{~mm}$ long shells. The differences in the percentage of dead and living individuals were compared using the Chi-square test with Yates correction and level d significance level of 0.05.

Records of the population of A. fulica in Santana neighborhoods in terms of abundance performed were compared between neighborhoods and checked if their differences were significant and also compared to the results of a past study by Sá-Oliveira et al. (2013) in same area of study, through Chi-square test with Yates correction and significance level of 0.05 .

To quantify the importance of environmental variables used Water conditions (flooded and dry), Food (fresh and processed) and Property cleaning aspect (appropriate and inappropriate) in determining the likelihood of individuals living and dead A. fulica we used the statistical model of logistic regression analysis. This method is the most efficient to model the occurrence of individuals (Quinn \& Keough, 2005), with advantage over the other for allowing the development of a predictive equation of the occurrence of species. The models were adjusted by using the maximum likelihood algorithm, aiming to test the null hypothesis that the importance of environmental variables is equal to zero. We used one (1) in cases of occurrence and zero (0) to absence of snails in each district, also used one (1) for the inappropriate variables (cleaning: inadequate), dry (hydro condition) and processed (food). All analyzes were performed using the Bioestat 5.3 software (Ayres et al., 2007).

\subsection{Perception of the Residents in Relation to A. fulica}

Questionnaires were applied with questions regarding the A. fulica the residents of the three neighborhoods studied (Amazon village, Central and Paradise) and socio-demographic data of respondents, without identifying them. Data regarding the perception of the residents were analyzed by percentage. To see if there were differences between the wage income of the residents of the three neighborhoods conducted an analysis of variance (ANOVA) with subsequent Tukey test and $\alpha=0.05$.

To verify that social factors such as level of education, income, household waste had influence on the occurrence of A. fulica in the three neighborhoods, there was a logistic regression analysis, using one (1) to cases of occurrence and zero (0) for lack of snails at each property; It is also used one (1) to low levels of education and low income. The models were adjusted using the maximum likelihood algorithm. These analyzes were performed using the software Bioestat 5.3 (Ayres et al., 2007).

\section{Results and Discussion}

The collections resulted in getting 419 molluscs identified as A. fulica in three neighborhoods of the Santana city, with 190 in Central, 172 in Paradise and 57 in the Amazon Village neighborhood. Regarding the percentage of individuals living and dead, there was predominance of living in Central and Paradise. In the Amazon Village 
neighborhood, there was a predominance of deaths, and these significant differences for the dead $(p<0.05)$ (Table 1). The Chi-square test showed significant differences in the abundance of $A$. fulica between the Amazon Village neighborhood with the center $\left(\chi^{2}=72.49 ; D F=1 ; p=0.0001\right)$ and the Paradise neighborhood $\left(\chi^{2}=\right.$ 55.40; $D F=1 ; p=0.0001)$, with no differences between the Centre and Paradise $\left(\chi^{2}=0.38 ; D F=1 ; p=0.58\right)$. These results suggest that environmental and social factors are acting positively in controlling the invasion of African snails in the Amazon Village neighborhood and that the same factors do not occur in the same way in the other two districts assessed.

With regard to organic substrates used by molluscs, found individuals in areas considered as composting, vegetables, organic waste, decaying wood, feces and litter, with a predominance in the litter in all size classes (large, medium and small). In Central and Vila Amazon quarters, most snails were on construction rubble, walls, wood surfaces and ornamental plants. Unlike in the Paradise neighborhood, most of the snails was associated with organic waste, fruiting vegetables, animal feces and decaying organic matter present in the buildings of this district. Food scraps and other organic waste in backyards and vacant lots, and provides substrates for $A$. fulica may also be used, favoring the establishment of this species in urban or disturbed areas (Fischer \& Colley, 2005; Sá-Oliveira, 2013).

In terms of population length structure, it observed that, in all quarters, most individuals showed variation in length between 30 and $75 \mathrm{~mm}$, featuring a younger population $(40-90 \mathrm{~mm}$ ) (Figure 2 (a) = Amazon Village, (b) = Central, (c) = Paradise), as Tomiyama (2002). The record length ( $\mathrm{Lt} \mathrm{mm}$ ) of individuals of each neighborhood,

Table 1. Percentage of individuals living and dead A. fulica three neighborhoods of the Santana, Amapá, Brazil.

\begin{tabular}{cccccc}
\hline Neighborhoods & $\mathbf{n}$ & Live (\%) & Dead (\%) & $\chi^{2}$ & $\boldsymbol{p}$ \\
\hline Central & 190 & 47.4 & 52.6 & 0.27 & 0.674 \\
Paradise & 172 & 44.8 & 55.2 & 1.08 & 0.327 \\
Amazon Village & 57 & 33.3 & 66.7 & 10.92 & 0.001 \\
\hline
\end{tabular}
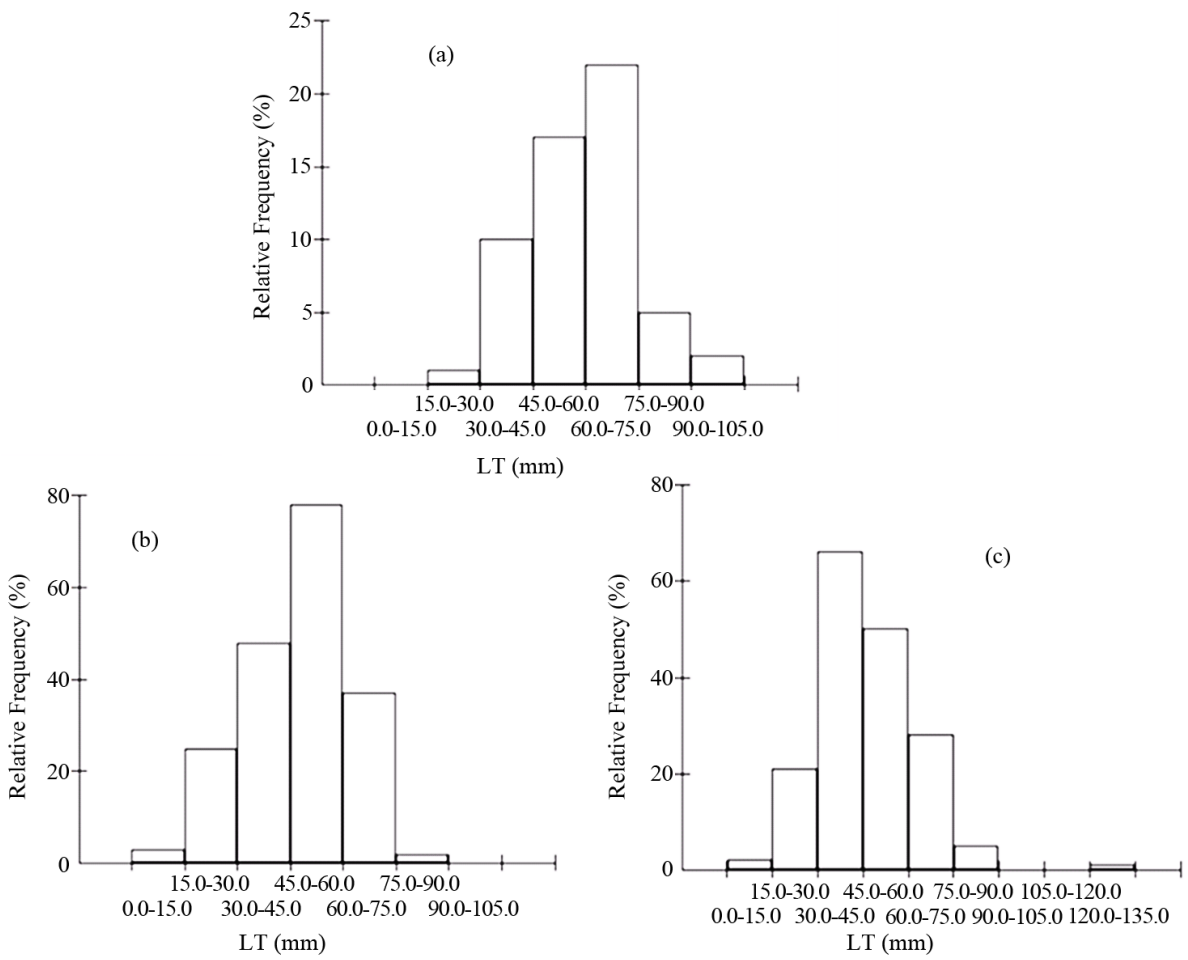

Figure 2. Population structure of A. fulica in three neighborhoods of the Santana, Amapá, Brazil. 
showed greater range of length for individuals in Paradise neighborhood. According to Tomiyama \& Nakane (1993), the dispersion of the species is most effective among young individuals. At this stage of development molluscs moving up to 15 meters per night, which in principle would allow the displacement of 500 meters in one semester (Tomiyama \& Nakane, 1993), which may explain the dispersion found in this study.

In some real estate (3) of the Amazon Village neighborhood was not registered the occurrence of african snails. In the Central, only a property was no snails and, at Paradise, the five homes showed occurrence of molluscs. Logistic regression analysis indicated that the occurrence of $A$. fulica individuals, living and dead, may be related to variables denoting anthropogenic environment, evidenced from the general predictive model: LogitY $=-2.4958+(0.3064 \mathrm{X} 1)+(3.9594 \mathrm{X} 2)+(1.2936 \mathrm{X} 3)$, as follows: $\mathrm{Y}=$ Occurrence; $\mathrm{X} 1$ = water condition; $\mathrm{X} 2=$ Cleaning; and $\mathrm{X} 3$ = food.

The analysis shows that the occurrence of A. fulica has 52 times more likely (odds ratio) to happen if the property is not cleaned properly. The variable property cleaning is responsible for $81.25 \%$ by the occurrence of shellfish (Table 2). When added Food variable, the probability of occurrence rises to clam 95\%, indicating that the occurrence of $A$. fulica is related to these variables. Model validation done by the likelihood function $\left(-2 \log ^{*}\right.$ likelihood $=12.25 ; \chi^{2}=14.48 ; D F=3, p=0.002$ ) was statistically significant, indicating that the model was suitable for the analysis.

Studies have shown that $A$. fulica is not demanding as regards its food, consumes at least 500 different plants, algae and lichens, also eat bone and dead meat, including limestone and walls to sources of calcium, which is considered a species that negatively impact the food chain (Prasad et al., 2004; Aquino, 2010). However, it was observed that when are available easiest foods such as organic waste, A. fulica uses them without going in search of natural foods such as plants.

Fischer \& Colley (2005) found that the snail has a preference for certain types of organic waste and the urban environment makes it easier to expand the foraging time and is one of the determining factors of the increase in the species growth. A large deposition of organic solid waste in urban environments is one of the determining factors favorable and the proliferation of $A$. fulica in cities.

According to Raut \& Barker (2002), the availability of different food resources that promotes choice and plenty of food, may have an important effect on population dynamics. These factors can influence the growth rate, survival, fertility and recruitment, since the takeover of different nutrients results in larger individuals in a short time. In addition to feeding paper and even wall paint, become cannibalistic, eating eggs and young of the same species, mainly in the absence of calcium (Ireland, 1991).

For all three neighborhoods grouped, population structure length which categorizes life stages of $A$. fulica shown that young subjects (67.1\%) were predominant, followed by individuals in the juvenile stage (32.7\%). Throughout the sample was captured only one individual in the adult stage $(0.2 \%)$ in the Paradise neighborhood. Juveniles were prevalent in neighborhoods Central, Paradise and Amazon Village (Figure 3).

The population growth of $A$. fulica in the three districts of Santana proved to be increasing in relation to the past study by Sa-Oliveira et al. (2013), around 90\% increase, as in the earlier study were 246 registered individuals and in this 419 individuals were recorded, noting that both recordings were made using the same sampling effort in the same areas. The Chi-square test with the results of the records of the two studies showed significant differences $\left(\chi^{2}=121.66 ; D F=1 ; p=0.0001\right)$, which confirms the clam population increase in the three districts of Santana.

When checked by quarters, it was observed that there was an increase in all but with a larger increase in the Central neighborhood compared to the past study (Paradise $=159$ ind.; Central $=55$ ind.; Amazon Village $=32$

Table 2. Logistic regression analysis of the influence of environmental characteristics of three neighborhoods of Santana on the occurrence of $A$. fulica.

\begin{tabular}{ccccccc}
\hline Variables & B & S.E. & Wald & df & Sig. $(\boldsymbol{p})$ & Odds ratio \\
\hline Water condition & 0.306 & 1.672 & 0.034 & 1 & 0.855 & 1.358 \\
Cleaning & 3.959 & 1.535 & 6.653 & 1 & 0.010 & 52.428 \\
Food & 1.294 & 1.537 & 0.708 & 1 & 0.400 & 3.646 \\
Constant & -2.496 & 1.794 & 1.936 & 1 & 0.164 & 0.082 \\
\hline
\end{tabular}

Variable(s) entered on step 1: Water condition: dry, Cleaning: inadequate, Food: handled. 


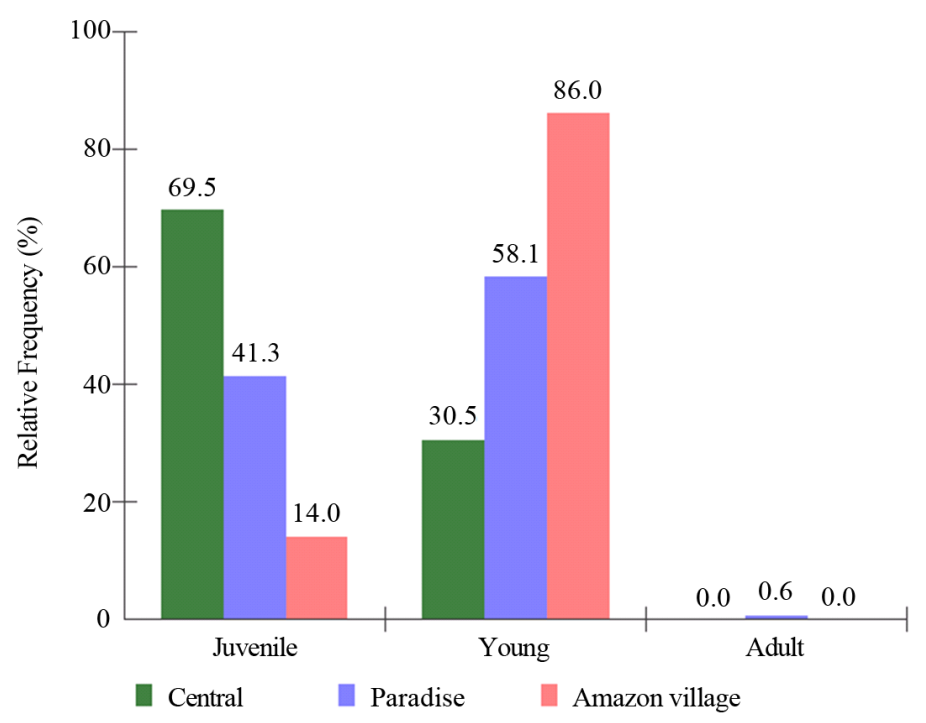

Figure 3. Stages of development of A. fulica in three neighborhood of Santana, Amapá, Brazil.

ind.) being the Amazon Village neighborhood with steady growth. The Chi-square test $\left(\chi^{2}=8713 ; D F=1 ; p=\right.$ 0.002 ) showed significant differences between records of the current study and past the downtown. In other districts the differences were not significant $(p>0.05)$. Sociodemographic profile and perception of the population in relation to A. fulica.

A total of 296 people surveyed, it was found that most have only $1^{\circ}$ degree (49.32\%), and residents of the Paradise neighborhood (73\%) over those who were in this condition. The inhabitants of the Amazon Village and Central were those with the highest educational level, with second and third degree $(>70 \%)$, and residents of Vila Amazon those with the highest percentage of higher level of educational background (Figure 4).

In relation to income, respondents residents of the district central were those with monthly income higher than 10 minimum wages (11.5 \pm 2.44$)$ ( 1 minimum wage $=$ US\$ 190.00). The Amazon Village neighborhood had an average monthly income of $6.00 \pm 2.16$ minimum wages, while residents of the Paradise neighborhood, those with an average monthly income of $4.70 \pm 2.53$. The differences between the monthly income of the Central's residents (most) compared to residents of other districts were significant (ANOVA: $F=6.21, p=0.001$; Tukey: $p<0.001$ ), and this difference in favor of the Central neighborhood residents. This income gap is due mainly to the commercial activity developed by most residents of this neighborhood.

In Paradise neighborhood, 54.5\% of respondents said living in low-lying areas, seasonally flooded, called hangover. In another way, all respondents (100\%) of the Amazon Village neighborhood reported that their immobiles were built in high areas that do not flood temporarily. Part of the Centro neighborhood of the respondents said they lived in low land areas (34.5\%) and partly in high areas (65.5\%). About 68\% of respondents had their own property, with the majority not performed regularly cleaning your home, except the inhabitants of the Amazon Village neighborhood, of which 93\% had clean their property.

Most respondents (60\%) knew about A. fulica and had observed the snail in their urban property and never viewed these molluscs out of the urban environment. Knowledge about the snail outside the urban area was only $10 \%$ of respondents, being observed in the Environmental Protection Area-APA Fazendinha. In this environmental protection unit there is a subnormal human cluster, with all the socio-environmental disputes that these communities have, as lack of sanitation, waste disposal, inadequate buildings, among others. Although the majority of respondents know the african snail, there is still significant part of the population (40\%) of the investigated districts that are unaware of the species, especially in the Paradise neighborhood, which could indicate either a lack of interest in this segment of the population for environmental issues, as the lower educational level of the same.

According to Costa-Neto \& Pacheco (2004), the way most societies perceive and expresse with respect to mollusk highlight the attitudes, feelings of contempt, fear and loathing that humans generally show the invertebrates. Studies show association of the A. fulica with schistosomiasis and transmission of other diseases 


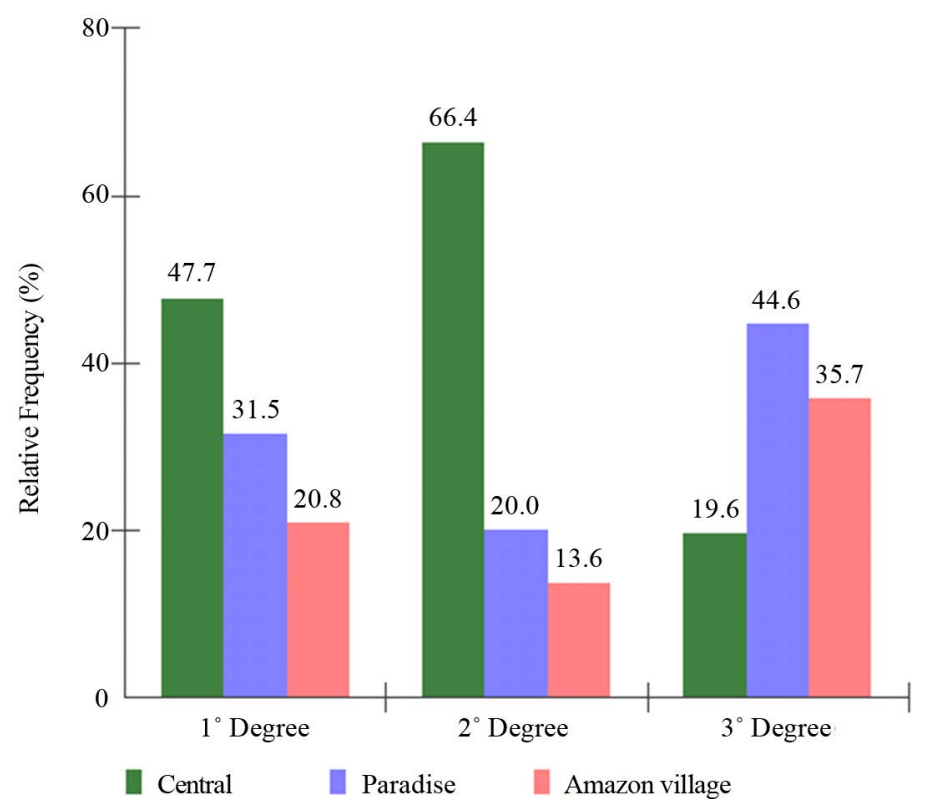

Figure 4. Level of education of the residents interviewed the three districts of the municipality of Santana, Amapá, Brazil.

(Rozemberg, 1994; Neuhauss et al., 2007; Diniz et al., 2003).

Achatina fulica, in nature, it feed of different types of plants (Kakoty \& Das, 1987; Tomiyama \& Nakane, 1993; Craze \& Mauremootoo, 2002). It is acceptable that the preference for the urban environment favors the increase of the species as it has a greater availability of shelters, chance of predators and variety and availability of food.

Regarding the popular designation of A. fulica, 73\% named the clam as snail. Other names were snail and slug. Sixty-five percent (65\%) of respondents knew differentiate it from other similar molluscs, most do Amazon Village (76.0\%) and a minority (8.0\%) of the Paradise neighborhood. Most (83\%) of the respondents' answers indicated that people's knowledge about the eating habits of A. fulica were vegetables, and about $77 \%$ said that their breeding season was the rainy season.

All respondents of the three neighborhoods responded that the increase in species density occurs in winter. Most respondents replied that the mollusk transmit diseases (80\%) and $25 \%$ of them could name a few diseases related to snail, as, meningitis, skin diseases and allergies, which are residents those residents of the Amazon Village neighborhood, which had higher educational level. Although about $40 \%$ of respondents have doubts on A. fulica related diseases. This suggests that respondents may be confusing or relating to species with those that transmit schistosomiasis (Biomphalaria sp.) and other native, not disease vectors.

Regarding the forms of population control of the species, $60 \%$ of the population does some form of control, and $73 \%$ of these use salt to kill, bury $15 \%$ and $12 \%$ incinerated snails. Most respondents (78\%) have pets and $30 \%$ of them said that dogs and cats have different reactions to snail, such as playing or eating and that the snails feed on the feces of these animals, which indicates the lack of proper cleaning of the property by the residents. All respondents said not eat and did not know anyone who eat or create A. fulica.

The general model predictive logistic regression analysis was: LogitY $=-3.982+(-4.401 \mathrm{X} 1)+(0.533 \mathrm{X} 2)+$ (0.936X3), as follows: $\mathrm{Y}=$ Occurrence; X1 = Educational level; X2 = Purchasing power; and X3 = Public cleaning. The validation of the model presented Function likelihood (likelihood $-2 \log ^{*}=19.11 ; \chi^{2}=16.24 ; D F$ $=3, p=0.00$ ) was statistically significant, indicating that the model was suitable for the analysis. Logistic regression indicated that the occurrence of fulica individuals may be related to variables denoting inadequate social habits, and that in the neighborhood where the absence of clam was evident, the level of education is higher.

The logit analysis shows that the occurrence of $A$. fulica has 89 times more likely (Odds Ratio) to happen if the property residents have low levels of education, indicating an inverse relationship between the occurrence of the snail in the property with the educational level of residents. Variables public cleaning and income of the residents do not have significant influence in shellfish occurrence in real estate of residents (Table 3). 
Table 3. Logistic regression analysis of the influence of the educational level of the residents three-Santana AP neighborhoods on the occurrence of $A$. fulica.

\begin{tabular}{cccccccc}
\hline Variables & B & S.E. & Wald & df & Sig. (p) & Odds ratio \\
\hline Educational level & -4.401 & 1.212 & 7.034 & 1 & 0.011 & 0.84 \\
Purchasing power & 0.533 & 1.149 & 0.027 & 1 & 0.22 \\
Public cleaning & 0.936 & 1.371 & 0.046 & 1 & 0.16 & 1.532 \\
Constant & -3.982 & 1.904 & 1.991 & 1 & 0.018 & 0.068 \\
\hline
\end{tabular}

Variable(s) entered on step 1: Educational level: low; Purchasing power: low; Public cleaning: inadequate.

When defendants about whether there was some action on environmental education to A. fulica in their neighborhoods, $100 \%$ of the interviewed said no, and those who had no mollusks in their homes said that the absence was due to the fact that they take the sanitation care in their homes, which inhibits the occurrence and installation of mollusks in their homes. This condition is related to the educational level that these individuals possess, with cleaning and sanitation habits.

Several studies indicate the power of transformation that education promotes in all human activities (Apple, 2003; Mayo, 2004). In the environmental area, the care that individuals accessing relevant education levels have attitudes conscious with proper sanitation is notorious (Alencar, 2005; SANEPAR, 2010; Eigenheer, 2013), environmental protection (Forlin\& Farias, 2002; Loureiro, 2004; Viégas \& Guimarães, 2004; Tozoni-Reis, 2006; Higuchi et al., 2012), agroecological farming and other environmentally sustainable food production (Layrargues, 2004; Crivellaro et al., 2008; Sá-Oliveira, 2015).

The education is responsible, along with training by the individual awareness process, for the discernment of right and wrong in the context of citizenship. Education can be considered as one among other social practices causing effects on people, creating necessary conditions for the necessary accomplishments to their quality of life (Frigotto, 2000). Nothing is done without the awareness and people's work, and all it has the power to alter the quality of consciousness and work, such as education, have the power to join his practice and be part of it (Brandão, 2002). In this study, respondents with higher educational level corroborate this statement, since they were able to transform reality posed by the invasion of snails, which are established in places with household garbage and other human waste.

In another way, Freire (2000) believes that education alone does not transform society, without it neither society changes. Education is an ongoing process and inherent to live, that is, to the extent that we live in different situations, we are educating. The day-to-day is educational, because individuals are creating and recreating ways to improve their social and environmental condition, and therefore, education is not neutral, it functions as a device to frame the logic of the political system, generating a situation of disagreement between individuals, when placed in inadequate situation charged by their level of education.

It is noteworthy that the individual education process occurs throughout his life. From birth, the individual takes on knowledge, values, skills in different environments existing in the society to which he belongs. Such social learning process lasts throughout its existence (Afonso et al., 2004). Despite some disagreement among scholars of the subject, the various forms of learning are distinguished in formal, non-formal and informal education (Brazil, 1997).

Respondents with higher purchasing power of the present study were not those with higher levels of education, but were those who gave less attention to the areas of hygiene practices which had established the snails. For this type of behavior, Freire (2002) reveals that the best reflection is inconclusive human being that has become conscious, acting like other animals, which are trained and uneducated, with ability to learn, not only to adapt, but also have thorough knowledge of transformation of reality by intervening in it and recreating it.

The transforming power of education leads the individual to relate knowledge, hypothesize, elucubration and act to prevent and mitigate unknown situations, but for logical understanding is able to discern whether it is adequate or not, as the case of invasion by A. fulica in households investigated. For Freire (2000), education can not be seen just inside the restricted mode of education only in itself but also in relation to other fields of knowledge capable of interpreting events.

The human being as a social biologically build your knowledge, your reality of meanings system in interaction with others and re-elaborates a dynamic and ongoing process (Kuhnen \& Higuchi, 2011). Education is cru- 
cial for the formation of the individual and influence his actions and attitudes in the course of a lifetime. First, the student must acquire the ability to "read the world around them", and then turn it. It's just to learn to "read the reality", aware of its responsibility and its role in society that this individual will not feel motivated to get involved with all forms of crime, either as victims or as author (Freire, 2002; Arantes, 2003), as well as avoid negative situations and harmful to society and the environment.

In this context, education is presented as a process of dynamic formation, transformer, comprehensive, permanent and participatory, where the people involved become change agents, actively participating in both the diagnosis of the problems, planning, implementation, monitoring and evaluation of the actions, the search for alternative and deploying solutions (Moises et al., 2010).

We emphasize that the work presented now is a pilot study to other studies concerning invasion of $A$. fulica in the state of Amapá, which may be performed by other researchers. Furthermore, this study serves as stimulus to the appropriate authorities to develop environmental education in educational units and in every city, with clear objectives to minimize the problems relating to the environment potentially present in the city.

\section{Conclusion}

In this study, it became apparent that residents with higher education levels were the ones who have careful hygiene with their properties, which directly influenced the non-installation of exotic species of snail, contributing indirectly with the environment by preventing invasive species interferes negatively on native species. In comparative with previous studies in the same area, it was observed that there was population growth of $A$. fulica in two of the three districts studied, suggesting population growth of the invasive species in Santana. The variables that contributed most to the occurrence and establishments of the species were lack of cleaning of the property and knowledge of the residents. On the other hand, the factor that minimized the occurrence and establishment of A. fulica in one of the city's neighborhoods was the level of education of its residents who become apt to develop prevention and elimination of mollusk.

\section{References}

Abramovay, R. (2012). Inequalities and Limitations Should Be in the Center of Rio + 20. Advanced Studies, São Paulo, 26, 21-33.

Afonso, S. R., Pádua, S., de Souza, M. G., Barreto, I. A. S., Peçanha, A., Carvalho, G., Ikeda, M. M., \& de Sá, F. C. N. (2004). Development Groups of Collective Performance/Cooperative as a Strategy for Environmental Education. Goiânia: V Brazilian Forum of Environmental Education. http://www.ceida.org/CD_CONGRESO_lus/documentacion_ea/comunicacions/EA_non_formal/ReginaAfonso_Sandra.html

Alencar, M. M. M. (2005). Recycling of Trash in a Public School in the City of Salvador. Revista Virtual, Candombá, 1, 96113. https://www.unisul.br/wps/wcm/connect/337a0de6-98d7-45ac-b273-0c36520a62a7/lixo_III.pdf?MOD=AJPERES

Alves, M. T. G., \& Soares, J. F. (2009). Socioeconomic Measures in Social Research: An Application to the Data of an Educational Research. Opinião Pública, Campinas, 15, 1-30. http://www.scielo.br/pdf/op/v15n1/a02v15n1

Angra, M. R. (2002). Scheme to Combat African Snail. Disponível em Matéria editada em 24 Jan. 2002.

Apple, M. W. (2003). Power, Meaning and Identity: Essays in Critical Educational Studies. New York: Peter Lang.

Aquino, M. (2010). Achatina fulica in Brazil. REDVET. Revista Electrónica de Veterinaria, 11, 1-7. http://www.veterinaria.org/revistas/redvet/n090910/091010.pdf

Arantes, V. A. (2003). Affection in School: Theoretical and Practical Alternatives. São Paulo: Summus Editorial.

Ayres, M., Ayres, J. R. M., Ayres, D. L., \& Santos, A. S. (2007). BioEstat 5.0-Statistics Applications in Areas of Biological and Medical Sciences: Sociedade Civil Mamirauá, Belém. Brasília: CNPq, 290 p.

Brandão, C. R. (2002). Education as Culture. Campinas: Mercado de Letras.

Brazil (1997). National Curriculum Parameters: Introduction of Transversal Themes and Ethics: Environment and Health. Brasília: MEC/SEF. 1v IEC/SEF.

Civeyrel, L., \& Simberloff, D. (1996). A Tale of Two Snails: Is the Cure Worse than the Disease? Biodiversity and Conservation, 5, 1231-1252. http://dx.doi.org/10.1007/BF00051574

Costa-Neto, E. M., \& Pacheco, J. M. (2004). The Construction of Ethnozoological Domain by Pedra Branca Villagers, Santa Terezinha, Estado da Bahia. Acta Scientiarum. Biological Science, 26, 81-90.

http://www.scielo.br/scielo.php?script=sci_nlinks\&ref=000105\&pid=S0001-3765200700020000700013\&lng=pt

Craze, P. G., \& Mauremootoo, J. R. (2002). A Test of Methods for Estimating Population Size of the Invasive Land Snail 
Achatina fulica in Dense Vegetation. Journal of Applied Ecology, 39, 653-660.

http://dx.doi.org/10.1046/j.1365-2664.2002.00744.x

Crivellaro, C. V. L., Castell, C. H. G. P., Silveira, I. M. L., Silva, K. G., Carvalho, R. V., \& Grosskopf, T. A. C. N. (2008). Nucleus of Education and Environmental Monitoring, Agroecology: A Friendly Way of Nature Conservation and Valorization of Life, Rio Grande. 28 p. http://www.aba-agroecologia.org.br/revistas/index.php/cad/article/viewFile/16523/10334

Diniz, M. C. P., Braga, R. B., \& Schall, V. T. (2003). Schistosomiasis Social Representations of School from Endemic Area of Minas Gerais. Ensaio-Pesquisa em Educação em Ciências, Belo Horizonte, 5, 54-71. http://www.redalyc.org/pdf/1295/129517970004.pdf

Duarte, R. (2002). Cinema \& Education. Belo Horizonte: Autêntica.

Eigenheer, E. M. (2013). Trash: Urban Cleaning through the Ages. Rio de Janeiro: Campus-Elsevier.

Fischer, M. L., \& Colley, E. (2005). Invasive Species in Nature Reserves: Characterization of the Achatinafulica Bowdich, 1822 (Mollusca-Achatinidae) on Ilha Rasa, Guaraqueçaba, Paraná. Brasil. Biota Neotropica, 5, 127-144. http://dx.doi.org/10.1590/S1676-06032005000100014

Forlin, F. S., \& Faria, J. A. F. (2002). Recycling of Plastic Packaging. Revista Polímeros: Ciência e Tecnologia, 12, 1-10.

Freire, P. (2000). The Pedagogy of Indignation-Pedagogical Letters and Other Writings. São Paulo: Unesp.

Freire, P. (2002). The Pedagogy of Autonomy-Knowledge Needed to Practice and Popular Education. São Paulo: Paz e Terra.

Frigotto, G. (2000). Education and Capitalism Crisis. São Paulo: Cortez.

Graeff-Teixeira, C. (2007). Expansion of Achatina fulica in Brazil and Potential Increased Risk for Angiostrongyliasis. Transactions of the Royal Society of Tropical Medicine and Hygiene, 101, 743-744. http://dx.doi.org/10.1016/j.trstmh.2007.03.012

Higuchi, M. I. G., Zattoni, M., \& Bueno, F. P. (2012). Environmental Education in Non-School Contexts: Defining, Discussing and Exemplifying. Pesquisa em Educação Ambiental, 7, 119-131. http://dx.doi.org/10.18675/2177-580X.vol7.n2.p119-132

Instituto Brasileiro de Geografia e Estatística-IBGE (2010). Census 2010: Population Characteristics and Households within Those.

http://www.brasileirosnomundo.itamaraty.gov.br/a-comunidade/estimativas-populacionais-das-comunidades/estimativas-d o-ibge/censo-demografico-ibge-2010.pdf

Ireland, M. P. (1991). The Effect of Dietary Calcium on Growth, Shell Thickness and Tissue Calcium Distribution in the Snail Achatina fulica. Comparative Biochemistry and Physiology, 98, 111-116. http://dx.doi.org/10.1016/0300-9629(91)90587-3

IUCN-The World Conservation Union (2000). 100 of the World’s Worst Invasive Alien Species. http://www.issg.org/

Kakoty, N. N., \& Das, S. C. (1987). The Giant African Snail Achatina fulica Bowdich a Non-Arthropod Pest. Two and a Bud, 34, 33-35.

Kuhnen A., \& Higuchi, M. I. G. (2011). Chapter 21: Environmental Perception. In S. Cavalcante, \& G. A. Elali (Org.), Topics in Environmental Psychology (pp. 250-266). Petropolis: Editora Vozes.

Layrargues, P. P. (2000). Education for Environmental Management: Citizenship in the Political Confrontation of Social and Environmental Conflicts. In C. F. B. Loureiro, P. P. Layrargues, \& R. S. Castro (Eds.), Society and the Environment: Environmental Education Debate (pp. 87-155). São Paulo: Cortez.

Layrargues, P. P. (2004). Identities of the Brazilian Environmental Education. Brasilia: Ministry of the Environment.

Loureiro, C. F. B. (2004). History and Fundamentals of Environmental Education. São Paulo: Cortez.

Mayo, P. G. (2004). Freire and Adult Education: Possibilities for Transformative Action. Porto Alegre: Artmed.

Moises, M., Kligerman, D. C., Cohen, S. C., \& Monteiro, S. C. F. (2010). The Federal Basic Sanitation Policy and Initiatives of Participation, Mobilization, Social Control, Health Education and Environmental Sanitation in Government Programs. Ciência \& Saúde Coletiva, 15, 2581-2591. http://www.scielo.br/pdf/csc/v15n5/v15n5a32.pdf

Nascimento, L. K., Chamy, P., \& Saldanha, I. (2003). The Infestation of Achatina fulica in the Ribeira Valley: A SocioEnvironmental Problems. Annals of the III Brazilian Congress of Environmental and Health Survey.

Neuhauss, E., Fitarelli, M., Romanzini, J., \& Graeff-Teixeira, C. (2007). Low Susceptibility of Achatina fulica from Brazil to Infection with Angiostrongylus costaricensis and A. cantonensis. Memórias do Instituto Oswaldo Cruz, 102, 49-52. http://dx.doi.org/10.1590/S0074-02762007000100007

Pimentel, D., McNair, S., Janecka, J., Wightman, J., Simmonds, C., O’Connell, C., Wong, E., Russel, L., Zern, J., Aquino, T., \& Tsomondo, T. (2001). Economic and Environmental Threats of Alien Plant, Animal, and Microbe Invasions. Agriculture, Ecosystems \& Environment, 84, 1-20. http://dx.doi.org/10.1016/S0167-8809(00)00178-X 
Prasad, G. S., Singh, D. R., Senani, S., \& Medhi, R. P. (2004). Eco-Friendly Way to Keep Away Pestiferous Giant African Snail, Achatina fulica Bowdich from Nursery Beds. Current Science, 87, 1657-1659. http://www.iisc.ernet.in/currsci/dec252004/1657.pdf

Quinn, G. P., \& Keough, M. J. (2005). Experimental Design and Data Analysis for Biologists (p. 537). Cambridge: Cambridge University Press.

Raut, S. K., \& Barker, G. (2002). Achatina fulica Bowdich and Others Achatinidae Pest in Tropical Agriculture. In G. Barker (Ed.), Mollusks as Croup Pest (pp. 55-114). New Zealand: CAB Publishing. http://dx.doi.org/10.1079/9780851993201.0055

Rozemberg, B. (1994). Social Representation of Somatic Events Related to Schistosomiasis. Cadernos Saúde Pública, 10, 30-46. http://dx.doi.org/10.1590/S0102-311X1994000100004

SANEPAR—Companhia de Saneamento do Paraná (2010). Annual Report of Management and Financial Statements 2010. Curitiba.

Sá-Oliveira, J. C., Correia, K. J. G., \& Vasconcelos, H. C. G. (2013). Achatina fulica Occurrence (Mollusca: Pulmonata: Achatinidae) in Three Neighborhoods of the City of Santana, Amapá. Biota Amazônia, 3, 9-12.

Sá-Oliveira, J. C., Gonçalves, T. S., Monteiro, P. R., Saraiva, I. O., \& Vasconcelos, H. C. G. (2012). Achatina fulica Occurrence (Mollusca: Pulmonata: Achatinidae) in Three Neighborhoods of the City of Macapá. Biota Amazônia, 2, 78-81.

Sá-Oliveira, J. C., Vasconcelos, H. C. G., \& Silva, E. S. (2015). Agroecology in the Perception of High School Students from Four Public Schools in the City of Macapa-Amapá. Biota Amazonia, 5, 98-107.

Sato, M. (2002). Environmental Education. São Carlos: Rima.

Saviani, D. (1985). School and Democracy (6th ed.). São Paulo: Cortez.

Tamoio, I. A. (2000). Meditation Teacher in the Construction of the Concept of Nature. Dissertation (Mestr.), Campinas: FE/ Unicamp.

Tedesco, J. C. (2012). Educación y justicia social en América Latina. Buenos Aires: Fondo de Cultura Económica, Universidad de San Martín. http://www.rinace.net/riejs/numeros/vol3-num2/recension2.pdf

Teles, H. M. S., \& Fontes, L. R. (2002). Implications of the Introduction and Spread of Achatina fulica Bowdich, 1882 in Brazil. Boletim do Instituto Adolfo Lutz, 12, 3-5.

Teles, H. M. S., Vaz, J. F., Fontes, L. R., \& Domingos, M. D. (1997). Achatina fulica Record Bowdich, 1822 (Mollusca, Gastropoda) in Brazil: Snail Intermediate Host of Angiostrongyliasis. Revista de Saúde Pública, 31, 310-312.

Tomiama, K., \& Nakane, M. (1993). Dispersal Patterns of the Giant African Snail, Achatina fulica (Ferussac) (Stylommatophora: Achatinidae), Equipped with a Radio transmitter. Journal of Molluscan Studies, 59, 315-322.

http://dx.doi.org/10.1093/mollus/59.3.315

Tomiyama, K. (1993). Growth and Maturation Pattern in the African Giant Snail, Achatina fulica (Férussac) (Stylommatophora: Achatinidae). Venus, 52, 87-100.

Tomiyama, K. (2002). Age Dependency of Sexual Role and Reproductive Ecology in a Simultaneously Hermaphroditic Land Snail, Achatina fulica (Stylommatophora: Achatinidae). Venus, 60, 273-283.

Tozoni-Reis, M. F. C. (2006). Environmental Issues as Generating Issues: Contributions to a Critical, Transforming and Emancipating Environmental Educating Methodology. Educar, 27, 93-110.

http://www.scielo.br/pdf/er/n27/a07n27.pdf

UCS-Union Concerned Scientist (2001). The Science of Invasive Species. http://www.scscb.org/working_groups/resources/invasive-species-science.pdf

Vasconcellos, M., \& Pile, E. (2001). Achatina fulica Occurrence in Vale do Paraíba, Rio de Janeiro, Brazil. Revista de Saúde Pública, 35, 582-584. http://dx.doi.org/10.1590/S0034-89102001000600013

Viégas, A., \& Guimaraes, M. (2004). Children and Education at School: Membership Required for a Better World? Revista Brasileira de Educação Ambiental, 1, 56-62. 